\title{
Kate Chopin's View on Death and Freedom in The Story of an Hour
}

\author{
Xuemei Wan \\ School of Foreign Languages, Jiangsu University Zhenjiang 212013, China
}

Tel: 86-511-8879-7843 E-mail: wanxuemei@ujs.edu.cn

This research is supported by the Education Department of Jiangsu Province, China from 2008 to 2010, among the Directing Projects on Philosophy and Social Sciences in Universities of Jiangsu Province, whose code is 08SJD7500021.

\begin{abstract}
The Story of an Hour, written by the American woman writer, Kate Chopin (1851-1904) fully shows us the tremendous conflict between life and death among those women who had the more self-awareness, the less social living space according to the established social norms 100 years ago in a dramatic way. The heroine's strong desire for freedom and sudden death remind us of the philosophical thought on life and death of Zhuangzi, ancient Chinese thinker and Martin Heideggar, which deconstruct and transcend the conflict between them.
\end{abstract}

Keywords: Kate Chopin, self-awareness, death, freedom, The Story of an Hour

In Aspects of the Novel, E. M. Forster (1974, p. 57) says, "The main facts in human life are five: birth, food, sleep, love and death" and "birth and death" are "the two strangest", for "death is coming even as birth has come, but, similarly, we do not know what it is like. Our final experience, like our first, is conjectural. We move between two darknesses". So it's no wonder that many novelists often take birth and death as the themes of their novels. It is also reflected in Kate Chopin's The Story of an Hour.

On April 19, 1894, Kate Chopin wrote "The Story of an Hour," a truly remarkable tale about a subdued wife's vision of intending to live only for herself. Louise Mallard, who suffers from heart trouble, is gently told the news of her husband's death in a railway-accident. She "wept at once, with sudden, wild abandonment"; then, "when the storm of grief had spent itself she went away to her room alone." As she sat looking as the spring life outside her window, her young face, "whose lines bespoke repression and even a certain strength," showed that something was coming to her which she tried in vain to hold back:

When she abandoned herself, a little whispered word escaped her slightly parted lips. She said it over and over under her breath: "free, free, free!"... She did not stop to ask if it were not a monstrous joy that held her. A clear and exalted perception enabled perception enabled her to dismiss the suggestion as trivial...

She saw... a long procession of years to come that would belong to her absolutely. And she opened and spread her arms out to them in welcome.

There was a feverish triumph in her eyes, and she carried herself unwittingly like a goddess of Victory...But Mr. Mallard had not been involved in the accident at all, and his unannounced return an hour later proved fatal to his wife:

When the doctors came they said she had died of heart disease---of joy that kills (Seyersted, 1980, pp. 57-58).

Louise Mallard was among that kind of women who were different from the traditional ones such as her sister. Facing the unexpectedly bad news, she was of course sad, however, at the same time she felt free, body and soul free. Her sister, Josephine, reminded us of her conventional thought that women should attach themselves to their husbands. She told Mrs. Mallard the shocking news in broken sentences, veiled hints that revealed in half concealing. Apparently, she would thought Mrs. Mallard could not bear the sadness when her sister closed herself in the room. In fact, Mrs. Mallard was drinking in the very elixir of life through that open window though she had blocked the door.

This astonishing story strongly indicates that how deeply Mrs. Mallard desired her own freedom, but there was a conflict between her life and death. She had her own contemplation about life such as love, marriage and freedom. But it was not an appropriate thing over hundred years ago for a lady to have her own ideas against the established ones. The story suggests us that Mrs. Mallard could live well if she had been a traditional lady, but she was not. On hearing the news, she was not alone with her sister and her husband's friend, Richard, but she was lonely. In real life, at that time, the social living space was large, but for Mrs. Mallard so small. No one could share her thoughts which were free. Therefore, she shut the door shedding those who disturbed her thinking even if they were her sister and her husband's friend, Richards.

"It is certain that 'Death' is coming", since the 'dying' of others is something that one experiences daily. Death is an undeniable "fact of experience" (Heidegger, 1999, p. 301). However, the thing seems a little different to Mrs. Mallard. It 
does not mean she would not die; anyway she had her own path "towards-death". Simone de Beauvoir has emphasized that she does not need to justify her existence as a wife and mother and that she can largely leave the responsibility for her fate to the man (Beauvoir, 1961, p. 13). Indeed the moment Mrs. Mallard feels it more important to be an individual than to be a woman (or at least a mother-woman), but she is in deep water. Unassisted, she has to create her own role and status and define her aims; she must fight society's opposition as well as her own feeling of insecurity and guilt, and - more than a man — she suffers and assumes sole responsibility for her life, which then depends on her own efforts; freedom becomes something of a negative condition and she herself is indeed a solitary soul.

Looking into Mrs. Mallard's psychological state, we could find that the emotional change must be described as the development of an increasingly resistant barrier between the real external world and that world which is most authentic in her experience - the inner world of her fantasies. Though in her deep heart there is an ardent longing for freedom and for female self-assertion, and beneath her reserve lies a strain of romanticism and rebelliousness, she has no chance to release from what she evidently felt as repression or frustration, thereby freeing forces that had lain dormant in her. Maybe it is such reasons that cause her heart trouble. Only when she was told the news of her husband's sudden death did she breathe the free and fresh air:

There would be no one to live for during those coming years; she would live for herself. There would be no powerful will bending hers in that blind persistence with which men and women believe they have a right to impose a private will upon a fellow-creature. A kind intention or a cruel intention made the act seem no less a crime as she looked upon it in that brief moment of illumination.

And yet she had loved him — sometimes. Often she had not. What did it matter! What could love, the unsolved mystery, count for in face of this possession of self-assertion which she suddenly recognized as the strongest impulse of her being!

"Free! Body and soul free!" she kept whispering. (Chopin, 1894)

Edmund Wilson discerningly points to "The Story of an Hour" as an example of the many unsatisfactory marriages in Kate Chopin's fiction (Seyersted189). Clearly, Mrs. Mallard, like Edna Pontellier in Chopin's The Awakening, leads a "dual life - that outward existence which conforms, the inward life which questions" since her social role conflicts with her true identity (Chopin 1969, p. 18).

During the course of her fancy running riot along those days ahead of her, Mrs. Mallard is gradually standing aloof from the social life and the people around her such as her husband, her sister, and her husband's friend, Richards. Perhaps she can derive some comfort from them, yet it is far from enough. Kate Chopin's view of life is to a large extent independent of such important currents of thought as idealism, socio-economic determinism, and even religion. Her attitude illustrated by Mrs. Mallard comes close to that of existentialism. She seems to say that Mrs. Mallard has a real existence only when she follows her own laws, and through conscious choice, becomes her own creation with an autonomous self. But while such a developmental freedom may strengthen the self, it is accompanied by a growing sense of isolation and aloneness, and even anguish. In this view, the conflict between Mrs. Mallard's life and death becomes so irreconcilable that she finally dies of heart disease when she is told that she will see her husband come back home alive instead of being dead in the railroad disaster.

Here Mrs. Mallard's passing away deconstructs the conflict between her life and death. It's difficult for us to agree with the doctors' view that it is joy that kills her. On the contrary, we are liable to consider that her death is caused by the great shock and anguish when she learns that her husband is still alive.

Edward W. Said in his "Traveling Theories" says:

Like people and schools of criticism, ideas and theories travel—from person to person, from situation to situation, from one period to another. Cultural and intellectual life are usually nourished and often sustained by this circulation of ideas, and whether it takes the form of acknowledged or unconscious influence, creative borrowing, or wholesale appropriation, the movement of ideas and theories from one place to another is both a fact of life and a usefully enabling condition of intellectual activity (Said, 1984, p. 226).

Thus when we review what Chopin has done in The Story of an Hour, we cannot help wondering that there are the others who have the similar ideas to her and what ideas and theories have influenced her. Kate Chopin must be familiar with the transcendentalist precursor Ralph Waldo Emerson (1803-1882), who emphasizes the importance of individual freedom and "that Unity" (Emerson, 1990, p. 155). In her The Awakening, she lets the heroine, Edna learn something from Emerson's works:

Then Edna sat in the library after dinner and read Emerson until she grew sleepy. She realized that she had neglected her reading studies, and determined to start anew upon a course of improving studies, now that her time was completely her own to do with as she liked" (Chopin, 1969, p. 96).

In his famous speech, "Liberty or Death" (1775), Patrick Henry (1736-1799) says, "I know not what course others may 
take; but as for me, give me liberty, or give me death!" Similarly, Zhuang Zi (B.C369 B.C.286?), an important representative of the Taoist school of thought in Chinese history, is very famous for his thought on freedom. He uses the story form to evoke the reader a philosophical response. Comparisons and parallels of Chopin's ideas on spiritual and physical freedom with Zhuang Zi's philosophy can reveal the universality of ideals of truth and morality encompassed by philosophical thought.

All his life Zhuang Zi lived in straitened circumstances and sometimes had to earn his rice by making straw sandals or even to borrow from others. But he was not at all interested in an official position or offering his service to any ruler. There was a king that went by with the name of Wei Wang in the State of Chu. When he was told that Zhuang Zi was very learned and talented, he sent an emissary to the latter, inviting him to become his prime minister with a huge salary. Zhuang $\mathrm{Zi}$ was adamant in declining the offer, and would rather be an orphaned piglet, saying, "I would rather play in a muddy ditch and be happy than be fettered by the state" (Yao-yu, 1991, p. 79). That means he would prefer never to have anything to do with the official world and hope for spiritual contentment only. Thus his spirit is free and he lives in perfect unity with himself and with nature, liberated from all moral, social, or political concerns, all metaphysical uneasiness, all concern for effectiveness, all internal or external conflict, and all wants and desires even though his body leads a dirty and miserable life.

In the same way, at the end of "The Story of an Hour", Mrs. Mallard seems to realize it's impossible for her to keep both her spirit and body free in the traditional society. After the sudden death, Mrs. Mallard gains the eternal spiritual freedom, melting into the universe. To some extent, she is not tragic and has taken fate in her own hands, making the supreme mastery over her destiny. From this point of view, maybe the doctors' diagnosis is right that Mrs. Mallard did die of joy, but the delight is not from the good news that her husband is still alive, but from the death in which she acquires an immortal freedom. All the conventional conflicts are deconstructed, and are not existent for her any longer. In short, the fact that Mrs. Mallard's life suddenly leaves her body is a good illustration of Heideggar's Being-towards-death.

Martin Heidegger (1889-1976), whom some judge "to be one of the greatest, if not the greatest, twentieth-century philosopher" (Johnson, 2000, p. 1), wants to develop a different way of understanding reality based on the question of being. He attempts to place this understanding of being in the arena of human being or Dasein. Dasein is in all cases you and me, your/my individual being. As Heidegger states Dasein is always already comporting itself towards being as if it knows what being is. Every living being has to be concerned about its being, and being is not a given (only death is). The individual's comportment toward being is very important in continuing being (avoiding death). In examining how we deal with others, Heidegger recognizes an inauthentic mode of being with others in our normal human condition. This is how we usually exist with others when we reflect on how we interact with others. The kind of being we find ourselves living is living the life of someone else, the "they". According to Heidegger, this is an inauthentic life, doing something that is not my own, but somebody else's.

Heidegger acknowledges that the "they" relieves my self of the burden of freedom, of being a self, freedom of choosing a self. For Heidegger, the self is something that must be resolutely chosen by Dasein. The usual state of being for Dasein is the "falling" of Dasein, which is a falling away from authentic being; tranquilized and alienated. In this "falling", Dasein is no longer aware of the need to be a self and is thereby removed or alienated from being a self. In response to this "falling", Dasein often experiences a feeling of anxiety. Anxiety is the mood/mode of attunement in which our inauthentic being is disclosed to us. For Heidegger, anxiety individualizes you. It is the way in which you are not dispersed in the "they".

An essential characteristic of Dasein is being of possibilities. Death is our utmost possibility. It is one of the possibilities of being which only I can be; no one else can do it for me. Death draws me to authenticity, away from "they", forces me to die my own death; and forces me to be authentic. When I am aware of my own death, I am closer to authenticity. Death is the reality, which makes it possible to escape inauthenticity. If I run forward to my own death, it makes me realize how individualized that I am and I am able to regain my own Being. It is easier to live, as everyone else does, less authentic and less anxious. But authentic living towards death is becoming responsible for my own choices.

For as much as this, in "The Story of an Hour", Mrs. Mallard wants to lead an authentic life, doing something that is her own, not somebody else's. She desires to make resolute choices outside the boundaries of the "they", outside of social conditioning and is fully aware of the possibility of what waits for her in the near future. The element of modern existentialism is fused with a Greek tragic sense of the cosmically inevitable as the author, at the very end, gives her heroine a meaning and a dimension which surpass the personal and contemporary boundary.

This is a very interesting and enlightening topic which I will discuss further. Heidegger's views force us into facing our life and death directly: we do not have a position outside of the world from which we can understand the world, "we cannot escape this aspect of our existence. Moreover, we are absorbed in this world" (Johnson 17). In fact, as long as we are alive, we are faced with a variety of possibilities. Even though we are aware that we are mortal, or at least become aware of this the older we become, we continue to think of the future. As Heideggar has pointed out, we are 
always ahead of ourselves. He says that in our everyday lives, absorbed as we are in the "they", we flee from death, and we can live our lives with a "freedom towards death" (Johnson, 2000, p. 28).

In literature, there are many protagonists who are granted deaths. Those characters have actualized their idealized images and then die before they are subject to failure and despair. There are many examples such as Flaubert's Emma Bovary (1857), Tolstoy's Anna Karenina (1877), and even Lin Dai-yu in a most famous Chinese writer, Cao Xueqin's The Story of the Stone (1763) in Qing Dynasty. Although those authors present their heroines as women struggling toward freedom and self-realization, they usually die in a horrible or agonizing way: Bovary is poisoned by arsenic, Anna is killed by a train, and Dai-yu, maybe we can say, dies of melancholia resulting from the feudal families' and social pressure. All the heroines live far from the nature, and become the victims of society. For example, throughout the novel, Flaubert maintains ironic distance from his protagonist: the reader more often observes than participates in Emma Bovary's awakening. But in "The Story of an Hour", Kate Chopin combines elements from Madame Bovary with a significant shift in focus. The ironic distance of Madame Bovary is replaced by a high degree of narrative sympathy. Written by a woman and focusing strictly upon changes of consciousness in its protagonist, "The Story of an Hour" represents a distilled example of the novel of feminist awakening and self-assertion, and the most essential part is the ending of the novel: Mrs. Mallard seems to die in tragedy, but it can be regarded as a triumph. Chopin grants her a death in which her cravings for freedom are finally fulfilled through her sudden joyful death.

All through her life, Kate Chopin must have been constantly shifting to adjust to the loss of he family members such as her father (in 1855), great-grandmother, brother, grandmother, her husband (in 1883), and her mother, and to her changing place in her personal community. Turning to escapist literature, she tried to forget the world and her grief. In time, she bounced back into life after she gained strength. No wonder, many of her protagonists including Mrs. Mallard seem to be searching for self-understanding in spite of the final death.

In a word, Chopin's philosophical ideas of life and death are clearly reflected in "The Story of Hour", which have transcended the irreconcilable conflict between life and death. They echo the philosophical thought of Zhuangzi, ancient Chinese thinker and Martin Heideggar on them and certainly there is still large space for us to probe. For example, her views also remind us of echofeminism and Chinese Unity of Heaven and Humanity as of ancient times, which I would discuss in another series of papers.

\section{References}

Beauvoir, Simone De. (1961). A History of Sex. London: Paperback. p.13.

Chopin, Kate. (1969). The Complete Works of Kate Chopin. Ed. Per Seyersted. Baton Rough: Louisiana State University Press. pp.18, 96.

Chopin, Kate. (1894). The Story of an Hour, [Online] Available: http://www.pbs.org/katechopin/library/storyofanhour.html(June 23, 2009)

Emerson, Ralph Waldo. (1990). Essays. New York: Vintage Books/The Library of America. p.155.

Forster, E. M. (1974). Aspects of the Novel. Ed. Stallybrass, Oliver. New York: Penguin Books, p.57.

Heidegger, Martin. (1999). Being and Time. Trans. John Macquarrie \& Edward Robinson. Beijing: China Social Sciences Publishing House. p. 301.

Johnson, Patricia Altenbernd. (2000). On Heidegger. USA: Wadsworth/Thomson Learning, Inc. p.28.

Said, Edward W. (1984). The World, the Text, and the Critic. London: Faber and Faber. p.226.

Seyersted, Per. (1980). Kate Chopin---A Critical Biography. New York: Octagon Books. pp.57-58, 189.

Yao-yu, Wu. (1991). The Taoist Tradition in Chinese Thought. Los Angeles: Ethnographics Press. p.79. 